\title{
KARAKTERISASI DAN ESTIMASI SUMBER DAYA GAMBUT SEBAGAI MATERIAL ADSORBEN LOGAM BERAT DALAM LARUTAN DI BLOK TELUK MERANTI, KABUPATEN PELALAWAN, PROVINSI RIAU
}

\section{CHARACTERIZATION AND RESOURCES ESTIMATION OF PEAT DEPOSIT AS HEAVY METAL ADSORBENT IN SOLUTION AT TELUK MERANTI BLOCK, PELALAWAN REGENCY, RIAU PROVINCE}

\author{
Muhammad Arief Pinandita ${ }^{1}$, Galuh Yuliani' ${ }^{2}$, Agus Subarnas ${ }^{1}$, \\ Denni Widhiyatna ${ }^{1}$, Maryono ${ }^{2}$, dan Siska Mutiara ${ }^{2}$ \\ ${ }^{1}$ Pusat Sumber Daya Mineral Batubara dan Panas Bumi, \\ ${ }^{2}$ Universitas Pendidikan Indonesia \\ muhammad.pinandita@esdm.go.id
}

\begin{abstract}
ABSTRAK
Indonesia memiliki areal gambut terluas di zona tropis, yaitu sebesar $70 \%$ di Asia Tenggara dan $50 \%$ dari lahan gambut tropis di dunia. Saat ini, pemanfaatan gambut masih relatif rendah, sedangkan ancaman kebakaran lahan gambut pada musim kemarau terus menjadi permasalahan serius di berbagai wilayah di Indonesia. Selain memiliki potensi sebagai sumber energi, gambut juga memiliki potensi untuk dimanfaatkan sebagai adsorben alami bagi logam berat. Penelitian ini bertujuan untuk melakukan karakterisasi gambut dan mengestimasi besarnya sumber daya gambut di Blok Teluk Meranti, Provinsi Riau yang dapat dimanfaatkan sebagai adsorben alami logam berat. Karakterisasi gambut dilakukan dengan pengujian conto gambut dengan kode PL-13, PL-21, dan PL-26 yang diperoleh dari Blok Teluk Meranti. Hasil uji luas permukaan menunjukkan luas permukaan PL-13, PL-21 dan PL-26 berturut-turut sebesar $241,73 \mathrm{~m}^{2} / \mathrm{g}, 241,80 \mathrm{~m}^{2} / \mathrm{g}$ dan $247,29 \mathrm{~m}^{2} / \mathrm{g}$. Hasil uji adsorpsi menunjukkan bahwa gambut PL-13, PL-21, dan PL-26 memiliki kapasitas adsorpsi maksimum berturut-turut sebesar 15,06; 11,99; dan 22,93 mg/g, serta efisiensi adsorpsi berturut-turut sebesar $46,79 \%$; 48,36\%; dan 46,85\%. Berdasarkan Peraturan Pemerintah Nomor 57 Tahun 2016, gambut yang memiliki ketebalan lebih dari tiga meter memiliki fungsi lindung, maka sumber daya tereka endapan gambut yang berpotensi untuk dimanfaatkan sebagai adsorben sebesar 90.477 .890 ton.
\end{abstract}

Kata kunci: adsorpsi, gambut, karakterisasi, kapasitas adsorpsi dan sumber daya

\section{ABSTRACT}

Indonesia has the largest peat area in the tropical zone, which represents $70 \%$ of the peat area in Southeast Asia and $50 \%$ of the world's tropical peatlands. At present, the utilization of peat is still relatively low and its likelihood to cause major fires during dry season is still of great concern in Indonesia. On the other hand, peat has potential to be used as natural adsorbent. This study aims to characterize the adsorptive properties of peat and to estimate its possible resources as natural heavy metal adsorbent in the Teluk Meranti Block. Peat characterization was carried out by selecting three peat samples, namely PL-13, PL-21 and PL-26 based on elemental analyses. The characterization of BET surface area showed that PL-13, PL-21, and $P L-26$ have maximum area of 241,73 $\mathrm{m}^{2} / \mathrm{g}, 241,80 \mathrm{~m}^{2} / \mathrm{g}$ dan $247,29 \mathrm{~m}^{2} / \mathrm{g}$, respectively. The adsorption test results show that PL-13, PL-21, and PL-26 have maximum capacity of 15.06; 11.99; and $22.93 \mathrm{mg} / \mathrm{g}$, with adsorption efficiencies of $46.79 \%$; $48.36 \%$; and $46.85 \%$, respectively. Based on Government Regulation No. 57 of 2016, peat with a thickness of three meters or more is determined as protection function of the peat ecosystem. Accordingly, the inferred resources of peat deposits that can be utilized as adsorbent is estimated to be $90,477,890$ tonnes.

Keywords: adsorption, adsorption capacity, characterization, peat and resources 


\section{PENDAHULUAN}

Secara alamiah, gambut didefinisikan sebagai material organik yang terbentuk akibat dekomposisi yang tidak sempurna dari tumbuh-tumbuhan di daerah basah dan dalam kondisi lembab serta kekurangan oksigen (Mirwan \& Wijayanti, 2011). Umumnya, gambut berwarna coklat muda hingga coklat tua sampai gelap kehitaman, sangat lunak, mudah ditusuk, mengotori tangan, bila diperas mengeluarkan cairan gelap dan meninggalkan ampas sisa tumbuhan (Tjahjono, 2007). Kadar air tanah gambut berkisar antara 100 s.d1.300\% dari berat keringnya (Agus \& Subiksa, 2008).

Karakteristik tanah gambut sangat ditentukan oleh kondisi geografis suatu daerah. Umumnya tanah gambut dimanfaatkan sebagai sumber energi alternatif dan bahan baku untuk mendapatkan senyawa organik, serta di bidang pertanian gambut banyak dimanfaatkan sebagai pupuk dan zat aditif untuk tanah (Boron, Evans, \& Peterson, 1987).

Di Indonesia, gambut telah terkumpul dan terbentuk sejak 5.000 tahun yang lalu (Holosen) dengan pembentuk utama adalah tumbuhan/hutan tropis (Mirwan \& Wijayanti, 2011). Indonesia memiliki areal gambut terluas di zona tropis, mencakup $70 \%$ areal gambut di Asia Tenggara dan $50 \%$ dari lahan gambut tropis di dunia. Lahan gambut Indonesia terpusat di tiga pulau besar, yaitu Sumatera (35\%), Kalimantan (32\%), Papua (30\%), dan pulau lainnya (3\%) dengan total luas 21 juta ha (Wahyunto \& Heryanto, 2005).

Saat ini, gambut menjadi salah satu permasalahan yang cukup besar di Indonesia. Bila terjadi kemarau panjang, lahan gambut akan kering selamanya (irreversible drying) dan gambut berubah sifat seperti arang. Hal tersebut menyebabkan gambut tidak mampu lagi menyerap hara dan menahan air, sehingga gambut mudah terbakar dan sulit dipadamkan (Yuleli, 2009). Gambut yang terbakar menghasilkan energi panas yang lebih besar dari kayu/arang terbakar. Gambut yang terbakar juga sulit dipadamkan dan apinya bisa merambat di bawah permukaan, sehingga kebakaran lahan bisa meluas dan tidak terkendali (Agus \& Subiksa, 2008).

Gambut di Indonesia memiliki kandungan mineral kurang dari $5 \%$ dan sisanya senyawa organik (Agus \& Subiksa, 2008). Senyawa-senyawa organik tersebut di antaranya lignin, senyawa polar yang mengandung gugus fungsi, seperti alkohol aldehid, keton, asam, hidroksi fenolik dan ikatan kimia lainnya. Adanya kandungan senyawa ini mengakibatkan gambut memiliki kapasitas perpindahan kation yang tinggi dan merupakan adsorben yang efektif untuk menghilangkan logam berat (Bailey dkk., 1999).

Bartczak dkk. (2018) dalam penelitiannya melaporkan gambut dapat menjadi adsorben logam berat, yakni ion logam nikel (II) dan timbal (II) dengan kapasitas adsorpsi maksimum untuk masing-masing ion logam $61,27 \mathrm{mg}\left(\mathrm{Ni}^{2+}\right) / \mathrm{g}$ dan 82,31 $\mathrm{mg}\left(\mathrm{Pb}^{2+}\right) / \mathrm{g}$. Mekanisme reaksi yang terjadi adalah adanya pertukaran ion antara gugus fungsi karboksil, fenolik, hidroksil dan lainnya dengan muatan positif ion nikel (II) dan timbal (II), serta membentuk senyawa kompleks. Hal ini membuktikan gambut cukup efektif untuk dimanfaatkan sebagai adsorben, dan termasuk kedalam adsorben yang memiliki harga relatif terjangkau.

Dalam penelitian ini dilakukan survei tinjau pemetaan gambut di daerah Blok Teluk Meranti, Kabupaten Pelalawan, Provinsi Riau, untuk mengetahui sebaran dan jumlah potensi gambut di daerah tersebut serta analisis peluang pemanfaatan gambut sebagai adsorben logam berat. Secara geografis, Kabupaten Pelalawan dibatasi oleh koordinat $00^{\circ} 46^{\prime} 24^{\prime \prime} \mathrm{LU}-00^{\circ}$ 24' 34" LS dan $101^{\circ} 30^{\prime} 37^{\prime \prime}$ BT - $103^{\circ} 21^{\prime}$ 36" BT (Gambar 1). 


\section{MAKALAH ILMIAH}

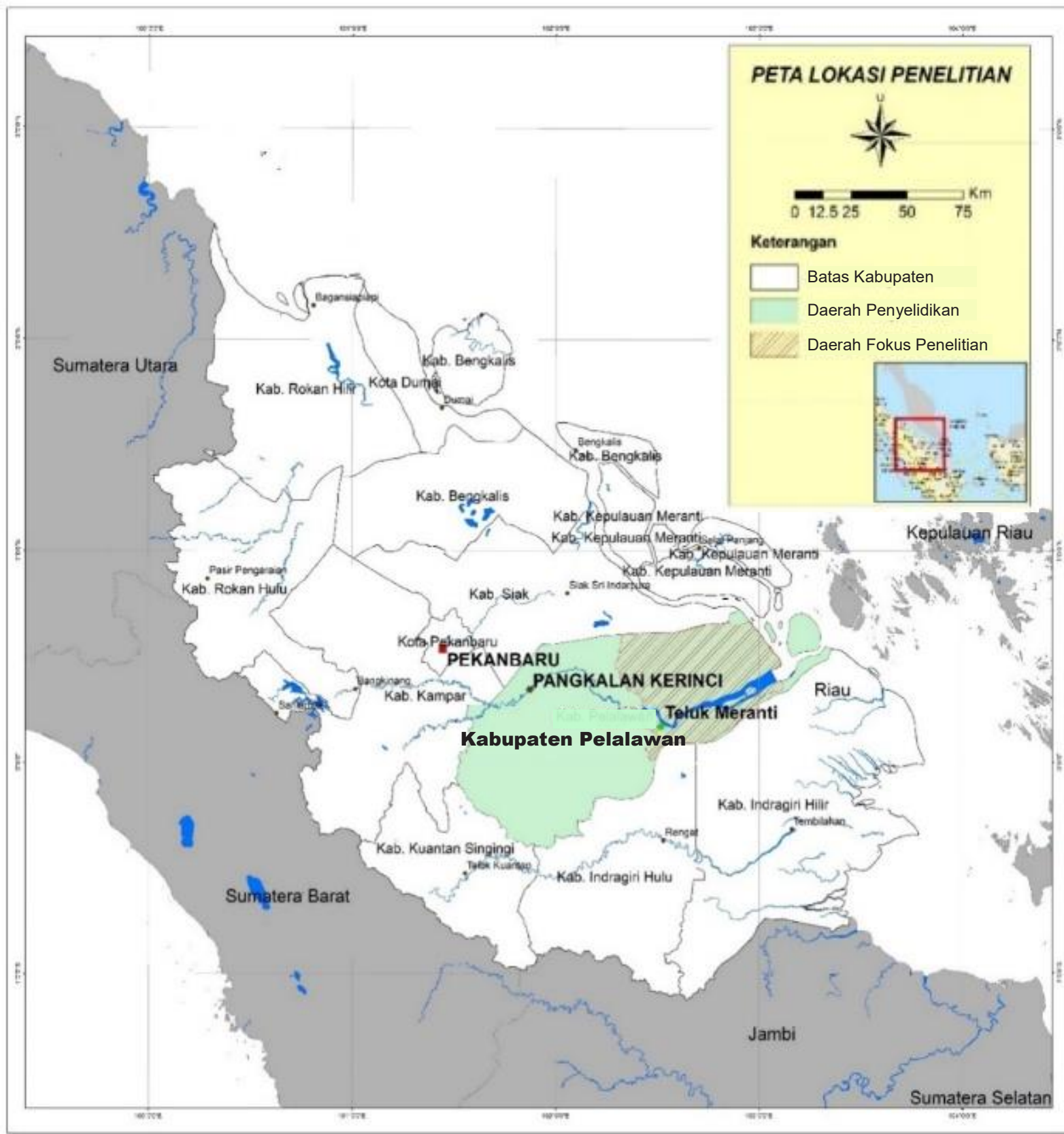

Gambar 1. Peta lokasi penelitian di daerah Teluk Meranti

\section{GEOLOGI}

\section{Morfologi}

Berdasarkan peta geologi, peta topografi dan peninjauan di lapangan, secara keseluruhan lokasi survei tinjau termasuk dalam zona dataran rendah dengan ketinggian antara $5 \mathrm{~m}$ s.d. $50 \mathrm{~m}$ dari permukaan laut. Morfologinya dapat dibagi dalam 2 satuan, yaitu: Dataran Rendah dan Perbukitan Bergelombang Landai (Gambar 2). Morfologi dataran rendah menempati sekitar $60 \%$ dari luas daerah survei tinjau, terutama pada bagian tengah menerus ke timur. Kearah timur, morfologi ini berkembang menjadi endapan rawa (Gambar 3) dan endapan pantai yang seluruhnya ditempati oleh endapan gambut. Kearah barat, endapan gambut sudah tidak terbentuk, hal ini dicirikan oleh keadaan topografinya dengan garis kontur menunjukkan angka yang makin tinggi diatas $20 \mathrm{~m}$ dari permukaan laut dan menjadi satuan morfologi perbukitan bergelombang landai. 


\section{MAKALAH ILMIAH}

Di daerah penelitian ini terdapat beberapa sungai yang cukup besar, yaitu Sungai Kampar, Sungai Selat Panjang dan anakanak sungainya. Sungai-sungai ini membentuk beberapa cekungan yang agak memanjang arah barat-timur yang terisi oleh endapan gambut. Hampir semua sungai-sungai ini mengalir ke arah barat.

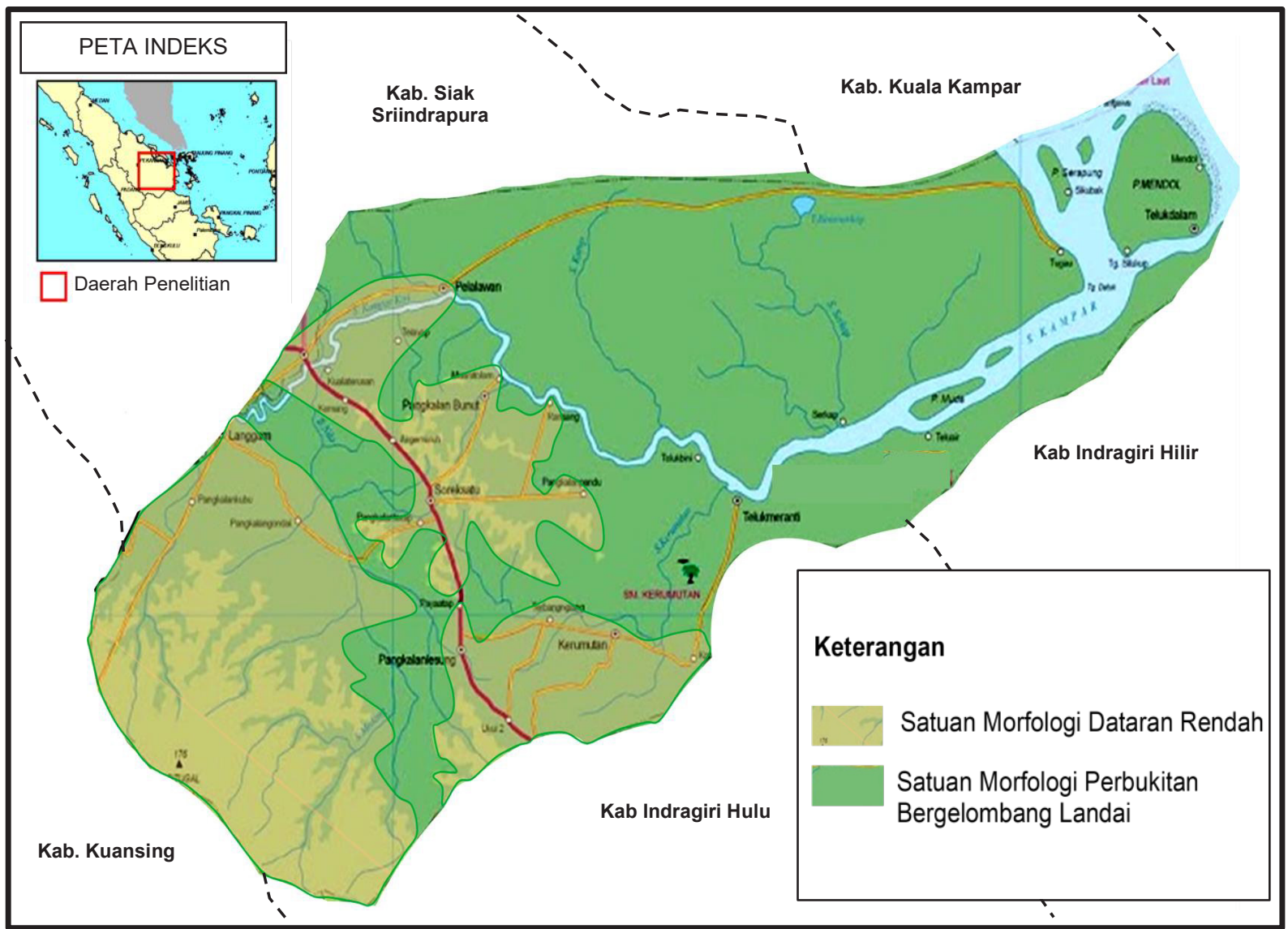

Gambar 2. Peta Satuan Morfologi Daerah Penelitian

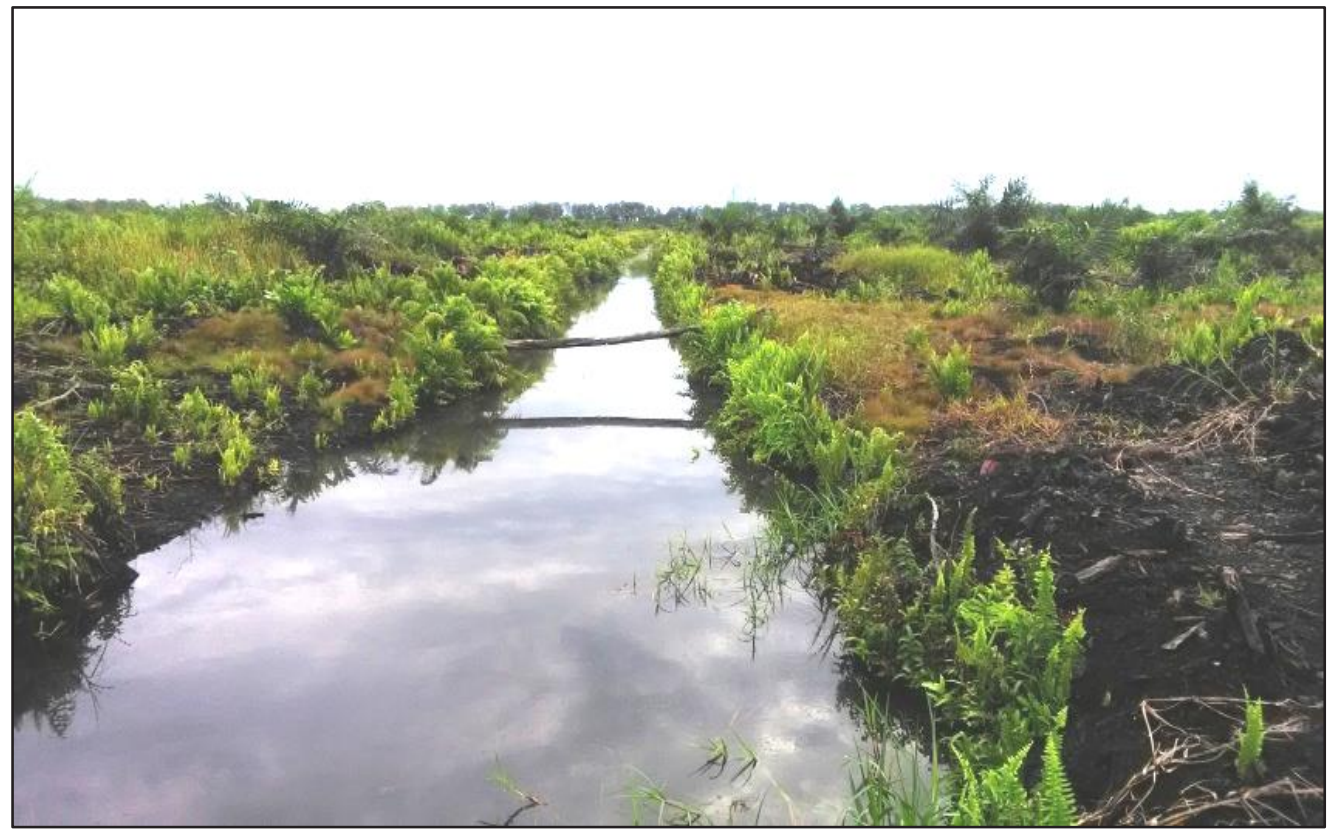

Gambar 3. Satuan Morfologi Dataran Rendah Berupa Endapan Rawa 


\section{Stratigrafi}

Stratigrafi pada daerah penelitian diurutkan dari tua ke muda tersusun oleh Granit Pulau Kundur berumur Kapur, Formasi Air Benakat dan Formasi Muara Enim berumur Miosen Akhir, Formasi Minas dan Formasi Kerumutan berumur Pliosen dan Plistosen, dan Endapan Kuarter berumur Holosen (Gambar 4) (Clarke dkk., 1982).

Di daerah penelitian, endapan gambut seluruhnya berada di Kecamatan Teluk Meranti. Cekungan gambut tersebut berada di antara tanggul Sungai Kampar dan tanggul Sungai Selat Panjang yang meliputi seluruh wilayah gambut yang ada di daerah Kabupaten Pelalawan. Dari hasil pengamatan, cekungan dan sebaran gambut menerus ke arah utara kedalam wilayah Kabupaten Siak Sri Indrapura.

Endapan Kuarter pada daerah penelitian dibagi menjadi beberapa jenis berdasarkan kondisi lingkungan pengendapannya dan material penyusunnya, yaitu:

- Aluvium, endapan ini dekat dan dipinggir sungai sebagai perluasan daratan. Endapan ini terdiri dari material lepas batulempung dan batupasir yang tersingkap di sekitar Sungai Kampar dan Sungai Selat Panjang.

- Endapan tanggul terbentuk di pinggir sungai dan berfungsi sebagai tanggul alam. Endapan ini terbentuk oleh endapan sungai pada saat banjir yang membawa material-material berukuran agak kasar dan kemudian diendapkan dipinggir sungai. Pada saat permukaan air maksimum, tanggul sungai ini lebih tinggi dan menjadi pemisah antara dataran banjir dengan sungai. Endapan tanggul ini terdiri dari material-material lempung, lanau dan pasir. Endapan tanggul di daerah penelitian merupakan Endapan Aluvial Tua (Qap).

- Undak sungai (Qrt), terjadi akibat erosi vertikal lebih dominan dibanding erosi lateral. Di daerah penelitian, undak sungai terdiri dari endapan aluvial yang membentuk morfologi pedataran. Endapan ini terdiri dari material kerikil, kerakal dan batupasir.

- Endapan organik, terbentuk pada bagian paling akhir dari dataran banjir. Pada bagian bawah, endapan organik bercampur dengan unsur-unsur anorganik, yaitu lempung dan lanau. Pada bagian atas terdapat endapan gambut yang disisipi oleh bagian tumbuhan seperti ranting, daun dan cabang yang telah membusuk yang disebut humus. Kondisi ini merupakan indikasi umum dari endapan gambut. Endapan ini di daerah penelitian termasuk dalam Endapan Rawa (Qs).

Endapan dasar gambut substrate, umumnya terdiri dari lempung dengan kandungan partikel-partikel organik, berwarna abu-abu terang sampai gelap, plastis dan mengandung organik.

Berdasarkan posisi stratigrafi dilapangan memperlihatkan endapan gambut berada diatas batulempung Formasi Minas dan diatas batulempung pasiran Formasi Kerumutan. Kedua formasi tersebut berumur Plio-Plistosen. 


\section{MAKALAH ILMIAH}

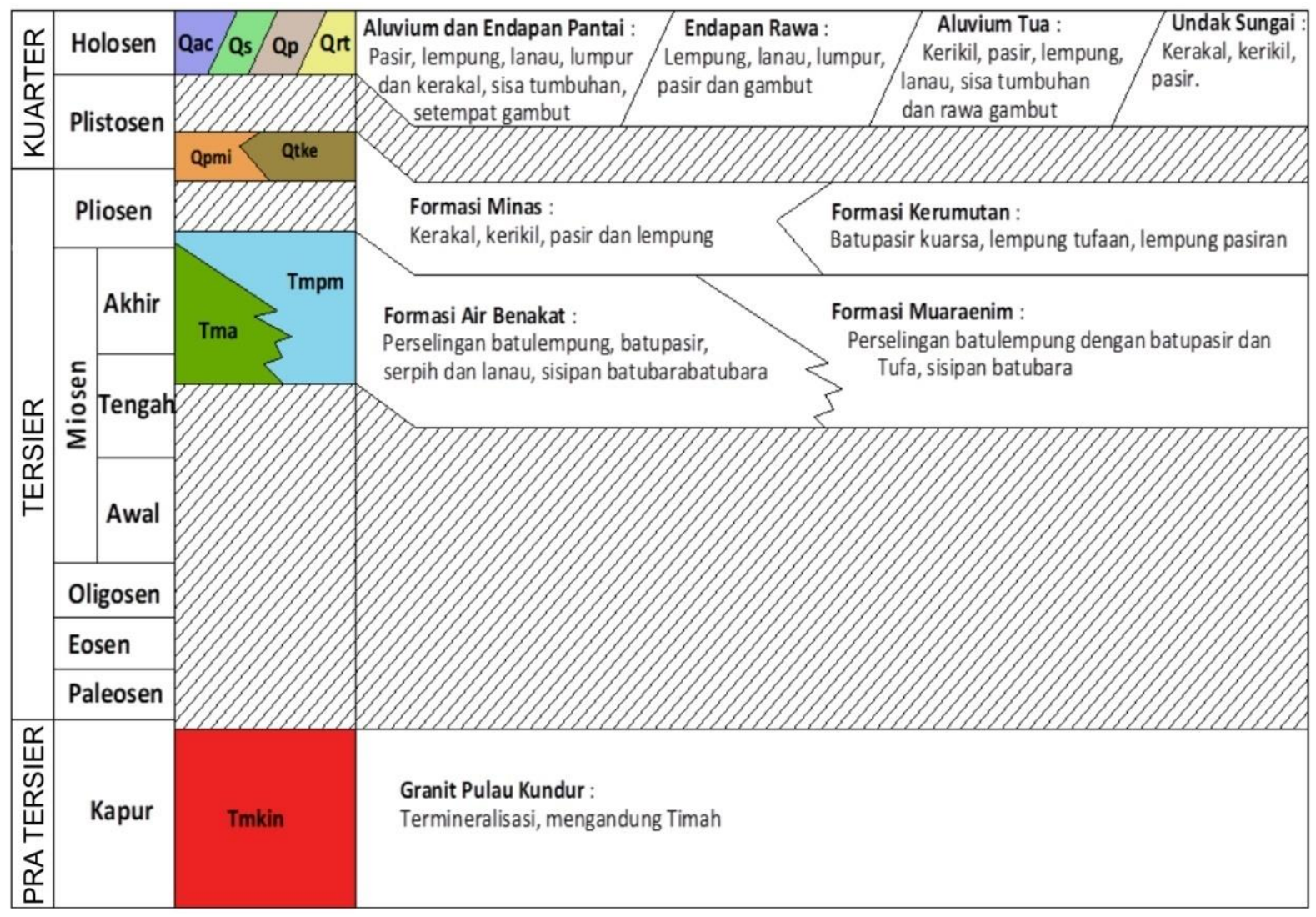

Gambar 4. Stratigrafi daerah penelitian (modifikasi Clarke dkk., 1982)

\section{METODOLOGI}

Kegiatan penelitian dibagi menjadi dua tahapan, yaitu tahapan kegiatan di lapangan dan tahapan analisis dan uji di laboratorium.

Kegiatan di lapangan meliputi:

- Pemetaan geologi untuk menentukan batas-batas penyebaran endapan gambut dan kontak endapan gambut dengan litologi lainnya, sekaligus melokalisasi sebaran gambut.

- Pengeboran dengan menggunakan alat bor khusus gambut jenis Fikelkarp Auger.

- Pemerian conto gambut secara megaskopis dari cutting hasil pengeboran gambut
- Pengambilan conto gambut untuk analisis laboratorium

Kegiatan di laboratorium meliputi:

- Analisis Proksimat, Ultimat dan Nilai Kalori

- Uji kadar air

- Analisis Luas Permukaan

- Analisis adsorpsi

\section{HASIL DAN PEMBAHASAN}

HASIL

\section{Pemetaan Endapan Gambut}

Berdasarkan hasil pemetaan geologi didapat data sebaran gambut yang diperoleh dari 56 titik pengeboran (Tabel 1) (Gambar 5). Gambut pada cekungan ini terbentuk di antara tanggul Sungai Kampar. 


\section{MAKALAH ILMIAH}

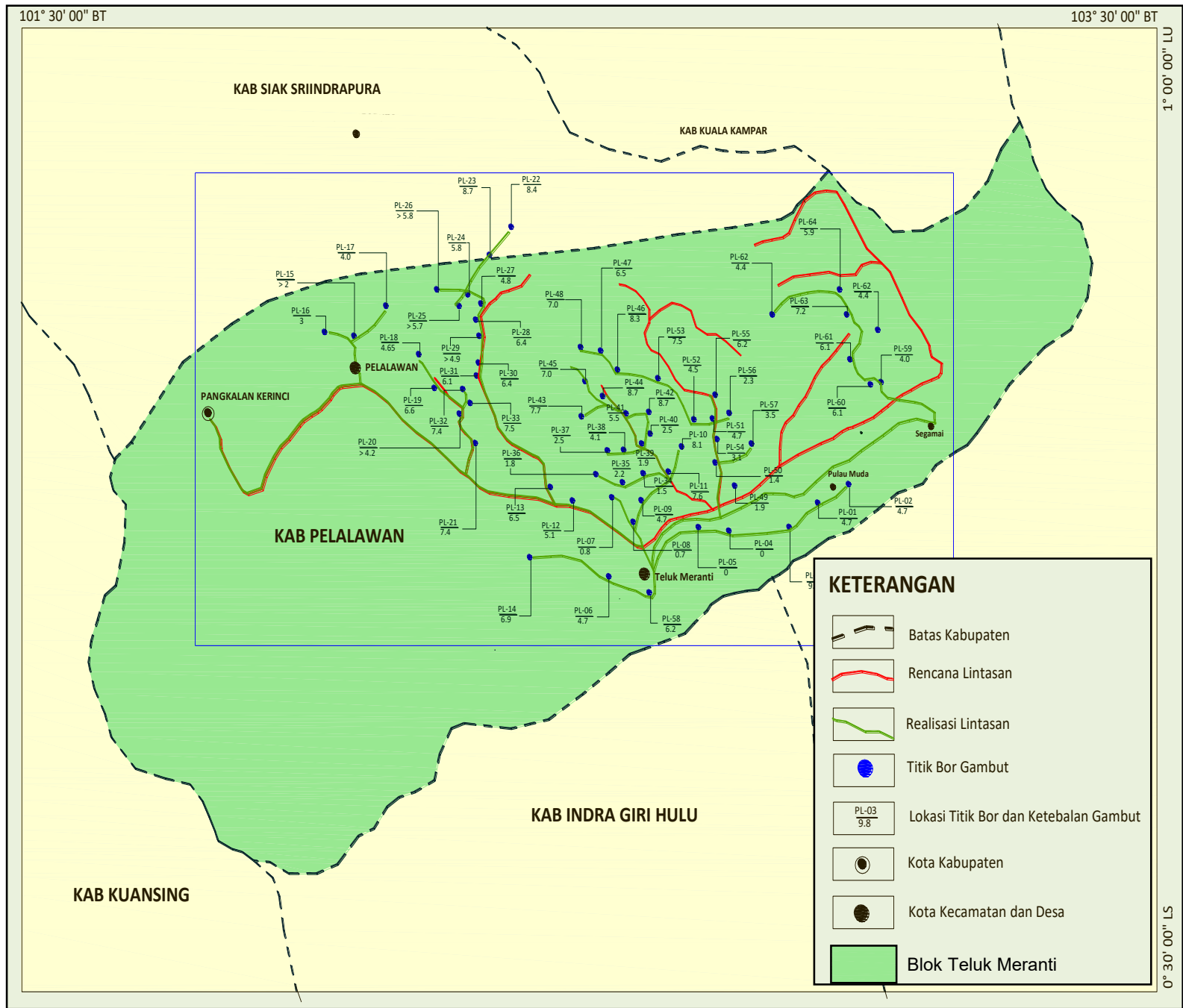

Gambar 5. Peta Lintasan dan Lokasi pengamatan

Tabel 1. Data gambut hasil pengeboran Blok Teluk Meranti

\begin{tabular}{|c|c|c|c|c|}
\hline No & $\begin{array}{c}\text { Titik } \\
\text { pengamatan }\end{array}$ & $\begin{array}{l}\text { Tebal } \\
(\mathrm{m})\end{array}$ & Conto & Pemerian \\
\hline 1 & PL-07 & 0,8 & & $\begin{array}{l}\text { Gambut, coklat, MAT }<1 \mathrm{~m} \text {, f, Low ash, Highly acidic, } \\
\text { H5-H8. }\end{array}$ \\
\hline 2 & PL-08 & 0,7 & & $\begin{array}{l}\text { Gambut, coklat, MAT }>1 \mathrm{~m} \text {, f, Low ash, Highly acidic, } \\
\text { H5-H8. }\end{array}$ \\
\hline 3 & PL-09 & 4,7 & $\sqrt{ }$ & $\begin{array}{l}\text { Gambut, coklat, MAT }>1 \mathrm{~m} \text {, f, Low ash, Highly acidic, } \\
\text { H5-H8. }\end{array}$ \\
\hline 4 & PL-10 & 8,1 & $\sqrt{ }$ & $\begin{array}{l}\text { Gambut, coklat kehitaman, MAT <1 m, f-h, Low ash, Highly } \\
\text { acidic, H5-H9. }\end{array}$ \\
\hline 5 & PL-11 & 7,6 & $\sqrt{ }$ & $\begin{array}{l}\text { Gambut, coklat kehitaman, MAT 0,8 m, f, Low ash, Highly } \\
\text { acidic, H5-H8. }\end{array}$ \\
\hline 6 & PL-12 & 5,1 & & $\begin{array}{l}\text { Gambut, coklat kehitaman, MAT 0,4 m, f-h, Low ash, Highly } \\
\text { acidic, H5-H9. }\end{array}$ \\
\hline 7 & PL-13 & 6,5 & $\sqrt{ }$ & $\begin{array}{l}\text { Gambut, coklat kehitaman, MAT } 1 \mathrm{~m} \text {, f-h, Low ash, Highly } \\
\text { acidic, H5-H9. }\end{array}$ \\
\hline 8 & PL-15 & $>2$ & & $\begin{array}{l}\text { Gambut, coklat kehitaman, MAT 0,8 m, f, Low ash, Highly } \\
\text { acidic, } \mathrm{H} 5-\mathrm{H} 8\end{array}$ \\
\hline 9 & PL-16 & 3,0 & $\sqrt{ }$ & $\begin{array}{l}\text { Gambut, coklat kehitaman, MAT <1 m, f-h, Low ash, Highly } \\
\text { acidic, H5-H9. }\end{array}$ \\
\hline
\end{tabular}




\section{MAKALAH ILMIAH}

\begin{tabular}{|c|c|c|c|c|}
\hline No & $\begin{array}{c}\text { Titik } \\
\text { pengamatan }\end{array}$ & $\begin{array}{c}\text { Tebal } \\
(\mathrm{m})\end{array}$ & Conto & Pemerian \\
\hline 10 & PL-17 & 4,0 & & $\begin{array}{l}\text { Gambut, coklat, MAT >1 m, f, Low ash, Highly acidic, } \\
\text { H5-H8. }\end{array}$ \\
\hline 11 & PL-18 & 4,65 & $\sqrt{ }$ & $\begin{array}{l}\text { Gambut, coklat, MAT }>1 \mathrm{~m}, \mathrm{f}-\mathrm{h} \text {, Low ash, Highly acidic, } \\
\text { H5-H9. }\end{array}$ \\
\hline 12 & PL-19 & 6,6 & $\sqrt{ }$ & $\begin{array}{l}\text { Gambut, coklat, MAT >1 m, f-h, Low ash, Highly acidic, } \\
\text { H5-H9. }\end{array}$ \\
\hline 13 & PL-20 & $>4,2$ & & $\begin{array}{l}\text { Gambut, coklat, MAT >1 m, f-h, Low ash, Highly acidic, } \\
\text { H5-H9. }\end{array}$ \\
\hline 14 & PL-21 & 7,4 & $\sqrt{ }$ & $\begin{array}{l}\text { Gambut, coklat kehitaman, MAT 0,7 m, f-h, Low ash, Highly } \\
\text { acidic, H5-H9. }\end{array}$ \\
\hline 15 & PL-22 & 8,4 & & $\begin{array}{l}\text { Gambut, coklat kehitaman, MAT } 1 \mathrm{~m} \text {, f-h, Low ash, Highly } \\
\text { acidic, H5-H9. }\end{array}$ \\
\hline 16 & PL-23 & 8,7 & $\sqrt{ }$ & $\begin{array}{l}\text { Gambut, coklat kehitaman, MAT } 1 \mathrm{~m} \text {, f-h, Low ash, Highly } \\
\text { acidic, H5-H9. }\end{array}$ \\
\hline 17 & PL-24 & 5,8 & $\sqrt{ }$ & $\begin{array}{l}\text { Gambut, coklat kehitaman, MAT 0,5 m, f-h, Low ash, Highly } \\
\text { acidic, H5-H9. }\end{array}$ \\
\hline 18 & PL-25 & $>5,7$ & $\sqrt{ }$ & $\begin{array}{l}\text { Gambut, coklat kehitaman, MAT } 1 \mathrm{~m} \text {, f-h, Low ash, Highly } \\
\text { acidic, H5-H9. }\end{array}$ \\
\hline 19 & PL-26 & $>5,8$ & $\sqrt{ }$ & $\begin{array}{l}\text { Gambut, coklat kehitaman, MAT < 1m, h, Low ash, Highly } \\
\text { acidic, H7-H9. }\end{array}$ \\
\hline 20 & PL-27 & 4,8 & $\sqrt{ }$ & $\begin{array}{l}\text { Gambut, coklat kehitaman, MAT } 1 \mathrm{~m} \text {, f-h, Low ash, Highly } \\
\text { acidic, H5-H9. }\end{array}$ \\
\hline 21 & PL-28 & 6,4 & & $\begin{array}{l}\text { Gambut, coklat, MAT } 0,7 \mathrm{~m} \text {, f, Low ash, Highly acidic, } \\
\mathrm{H} 5-\mathrm{H} 8\end{array}$ \\
\hline 22 & PL-29 & $>4,9$ & & $\begin{array}{l}\text { Gambut, coklat kehitaman, MAT 0,8 m, f, Low ash, Highly } \\
\text { acidic, H5-H8 }\end{array}$ \\
\hline 23 & PL-30 & 6,4 & & $\begin{array}{l}\text { Gambut, coklat kehitaman, MAT } 1 \mathrm{~m} \text {, f-h, Low ash, Highly } \\
\text { acidic, H5-H9. }\end{array}$ \\
\hline 24 & PL-31 & 6,1 & & $\begin{array}{l}\text { Gambut, coklat kehitaman, MAT } 1 \mathrm{~m} \text {, f-h, Low ash, Highly } \\
\text { acidic, H5-H9. }\end{array}$ \\
\hline 25 & PL-32 & 7,4 & & $\begin{array}{l}\text { Gambut, coklat kehitaman, MAT } 1 \mathrm{~m} \text {, f-h, Low ash, Highly } \\
\text { acidic, H5-H9. }\end{array}$ \\
\hline 26 & PL-33 & 7,5 & & $\begin{array}{l}\text { Gambut, coklat kehitaman, MAT } 1 \mathrm{~m} \text {, f-h, Low ash, Highly } \\
\text { acidic, H5-H9. }\end{array}$ \\
\hline 27 & PL-34 & 1,7 & & Gambut, coklat, MAT 1 m, f, Low ash, Highly acidic, H5-H8 \\
\hline 28 & PL-35 & 2,0 & & Gambut, coklat, MAT $1 \mathrm{~m}, \mathrm{f}$, Low ash, Highly acidic, H5-H8 \\
\hline 29 & PL-36 & 1,8 & & Gambut, coklat, MAT 1 m, f, Low ash, Highly acidic, H5-H8 \\
\hline 30 & PL-37 & 2,3 & & Gambut, coklat, MAT 1 m, f, Low ash, Highly acidic, H5-H8 \\
\hline 31 & PL-38 & 3.8 & & $\begin{array}{l}\text { Gambut, coklat kehitaman, MAT } 1 \mathrm{~m}, \mathrm{f}-\mathrm{h}, \text { Low ash, Highly } \\
\text { acidic, H5-H9. }\end{array}$ \\
\hline 32 & PL-39 & 1,9 & & $\begin{array}{l}\text { Gambut, coklat, MAT >1 m, f, Low ash, Highly acidic, } \\
\text { H5-H8 }\end{array}$ \\
\hline 33 & PL-40 & 2,2 & & Gambut, coklat, MAT 1 m, f, Low ash, Highly acidic, H5-H8 \\
\hline 34 & PL-41 & 4,7 & & $\begin{array}{l}\text { Gambut, coklat, MAT <1 m, f, Low ash, Highly acidic, } \\
\text { H5-H8 }\end{array}$ \\
\hline 35 & PL-42 & 7,8 & & $\begin{array}{l}\text { Gambut, coklat, MAT <1 m, f, Low ash, Highly acidic, } \\
\text { H5-H8 }\end{array}$ \\
\hline 36 & PL-43 & 7,4 & & $\begin{array}{l}\text { Gambut, coklat kehitaman, MAT <1 m, f-h, Low ash, Highly } \\
\text { acidic, H5-H9. }\end{array}$ \\
\hline 37 & PL-44 & 8,0 & & $\begin{array}{l}\text { Gambut, coklat kehitaman, MAT } 1 \mathrm{~m} \text {, f-h, Low ash, Highly } \\
\text { acidic, H5-H9. }\end{array}$ \\
\hline 38 & PL-45 & 6,7 & & $\begin{array}{l}\text { Gambut, coklat kehitaman, MAT } 1 \mathrm{~m} \text {, f-h, Low ash, Highly } \\
\text { acidic, H5-H9. }\end{array}$ \\
\hline
\end{tabular}




\section{MAKALAH ILMIAH}

\begin{tabular}{|c|c|c|c|c|}
\hline No & $\begin{array}{c}\text { Titik } \\
\text { pengamatan }\end{array}$ & $\begin{array}{c}\text { Tebal } \\
(\mathrm{m})\end{array}$ & Conto & Pemerian \\
\hline 39 & PL-46 & 8,1 & & $\begin{array}{l}\text { Gambut, coklat kehitaman, MAT } 1 \mathrm{~m} \text {, f-h, Low ash, Highly } \\
\text { acidic, H5-H9. }\end{array}$ \\
\hline 40 & PL-47 & 6,7 & & $\begin{array}{l}\text { Gambut, coklat kehitaman, MAT } 1 \mathrm{~m} \text {, f-h, Low ash, Highly } \\
\text { acidic, H5-H9. }\end{array}$ \\
\hline 41 & PL-48 & 6,7 & & $\begin{array}{l}\text { Gambut, coklat kehitaman, MAT 0,7 m, f-h, Low ash, Highly } \\
\text { acidic, H5-H9. }\end{array}$ \\
\hline 42 & PL-49 & 1,9 & & $\begin{array}{l}\text { Gambut, coklat kehitaman, MAT }>1 \mathrm{~m}, \mathrm{f} \text {, Low ash, Highly } \\
\text { acidic, } \mathrm{H} 5-\mathrm{H} 8\end{array}$ \\
\hline 43 & PL-50 & 1,4 & & $\begin{array}{l}\text { Gambut, coklat, MAT } 0,8 \mathrm{~m} \text {, f, Low ash, Highly acidic, } \\
\text { H5-H8 }\end{array}$ \\
\hline 44 & PL-51 & 4,7 & & $\begin{array}{l}\text { Gambut, coklat kehitaman, MAT }<1 \mathrm{~m}, \mathrm{f} \text {, Low ash, Highly } \\
\text { acidic, H5-H8 }\end{array}$ \\
\hline 45 & PL-52 & 4,7 & & $\begin{array}{l}\text { Gambut, coklat kehitaman, MAT }<1 \mathrm{~m}, \mathrm{f} \text {, Low ash, Highly } \\
\text { acidic, } \mathrm{H} 5-\mathrm{H} 8\end{array}$ \\
\hline 46 & PL-53 & 7,1 & & $\begin{array}{l}\text { Gambut, coklat kehitaman, MAT }<1 \mathrm{~m}, f-h, \text { Low ash, Highly } \\
\text { acidic, H5-H9 }\end{array}$ \\
\hline 47 & PL-54 & 3,1 & & $\begin{array}{l}\text { Gambut, coklat, MAT }>1 \mathrm{~m} \text {, f, Low ash, Highly acidic, } \\
\text { H5-H8 }\end{array}$ \\
\hline 48 & PL-55 & 5,8 & & $\begin{array}{l}\text { Gambut, coklat, MAT <1 m, f-h, Low ash, Highly acidic, } \\
\text { H5-H9 }\end{array}$ \\
\hline 49 & PL-56 & 3,8 & & $\begin{array}{l}\text { Gambut, coklat, MAT } 0,8 \mathrm{~m}, \mathrm{f}, \text { Low ash, Highly acidic, } \\
\mathrm{H} 5-\mathrm{H} 8\end{array}$ \\
\hline 50 & PL-57 & 3,8 & & $\begin{array}{l}\text { Gambut, coklat kehitaman, MAT } 0,8 \mathrm{~m}, \mathrm{f}, \text { Low ash, Highly } \\
\text { acidic, H5-H8 }\end{array}$ \\
\hline 51 & PL-59 & 4,0 & $\sqrt{ }$ & $\begin{array}{l}\text { Gambut, coklat, MAT }<1 \mathrm{~m}, f \text {, Low ash, Highly acidic, } \\
\text { H5-H8 }\end{array}$ \\
\hline 52 & PL-60 & 4,6 & & $\begin{array}{l}\text { Gambut, coklat, MAT <1 m, f, Low ash, Highly acidic, } \\
\text { H5-H8 }\end{array}$ \\
\hline 53 & PL-61 & 6,1 & & $\begin{array}{l}\text { Gambut, coklat kehitaman, MAT }<1 \mathrm{~m}, f-h \text {, Low ash, Highly } \\
\text { acidic, } \mathrm{H} 5-\mathrm{H} 9\end{array}$ \\
\hline 54 & PL-62 & 4,4 & $\sqrt{ }$ & $\begin{array}{l}\text { Gambut, coklat, MAT <1 } \mathrm{m}, f \text {, Low ash, Highly acidic, } \\
\mathrm{H} 5-\mathrm{H} 8\end{array}$ \\
\hline 55 & PL-63 & 7,2 & & $\begin{array}{l}\text { Gambut, coklat kehitaman, MAT }<0,7 \mathrm{~m}, f \text {, Low ash, Highly } \\
\text { acidic, } \mathrm{H} 5-\mathrm{H} 8\end{array}$ \\
\hline 56 & PL-64 & 5,9 & $\sqrt{ }$ & $\begin{array}{l}\text { Gambut, coklat kehitaman, MAT }<0,7 \mathrm{~m}, f \text {, Low ash, Highly } \\
\text { acidic, } \mathrm{H} 5-\mathrm{H} 8\end{array}$ \\
\hline
\end{tabular}

Catatan: MAT= Muka Air Tanah

\section{Kualitas Gambut}

Kualitas gambut ditentukan oleh hasil analisis kimia berupa analisis proksimat, ultimat dan nilai kalori (Tabel 2). Gambut di daerah penelitian memperlihatkan nilai kalori rata-rata $5.079 \mathrm{kal} / \mathrm{gram}$ (adb), kandungan abu rata-rata $0,23 \%$, sulfur total rata-rata $0,20 \%$ (termasuk sangat rendah), kandungan inherent moisture rata-rata $9,06 \%$ dan kandungan karbon tertambat sebesar $30,46 \%$. Hasil analisis ultimat menunjukkan nilai karbon rata-rata $62,39 \%$, hidrogen sekitar $5,26 \%$, nitrogen $1,13 \%$, sulfur $0,23 \%$ dan oksigen $31,10 \%$.
Uji Endapan Gambut Sebagai Adsorben Karakterisasi endapan gambut dilakukan dengan melakukan uji kadar air, analisis ultimat, uji luas permukaan dan uji potensi adsorben pada tiga conto terpilih, yaitu PL.13, PL.21 dan PL.26. Uji kadar air dilakukan untuk mengetahui jumlah air yang terkandung dalam gambut. Hasil uji kadar air ditunjukkan pada Gambar 6 . Berdasarkan diagram batang diketahui bahwa gambut PL-26 memiliki kadar air yang paling tinggi sebesar $88,77 \%$, sementara PL-21 dan PL-13 sebesar $87,93 \%$ dan $87,16 \%$. 


\section{MAKALAH ILMIAH}

Tabel 2. Data kualitas gambut Blok Teluk Meranti

\begin{tabular}{lllll}
\hline Parameter & Unit & Basis & Kisaran & Rata-rata \\
\hline Lembab Nisbi & $\%$ & ar & $82,90-91,77$ & 89,17 \\
\hline $\begin{array}{l}\text { Lembab } \\
\text { Jumlah }\end{array}$ & $\%$ & ar & $84,45-92,66$ & 90,15 \\
\hline Proksimat & & & & \\
\hline Kadar air & $\%$ & adb & $8,40-10,34$ & 9,06 \\
\hline Zat Terbang & $\%$ & adb & $54,67-60,17$ & 57,95 \\
\hline Karbon & $\%$ & adb & $27,40-32,45$ & 30,46 \\
\hline Tertambat & $\%$ & adb & $0,64-6,37$ & 2,39 \\
\hline Abu & $\%$ & adb & $0,11-0,40$ & 0,20 \\
\hline Sulfur total & $\%$ & adb & $0,08-0,13$ & 0,10 \\
\hline Berat Jenis & $\%$ & & $3,51-5,16$ & 4,12 \\
\hline PH & & adb & $4.895-5.389$ & 5.079 \\
\hline Nilai Kalori & Kal/gr & & & \\
\hline Ultimat & & daf & $61,34-64,35$ & 62,39 \\
\hline Karbon & $\%$ & daf & $5,01-5,48$ & 5,26 \\
\hline Hidrogen & $\%$ & daf & $28,99-32,08$ & 31,10 \\
\hline Oksigen & $\%$ & daf & $0,92-1,42$ & 1,13 \\
\hline Nitrogen & $\%$ & daf & $0,12-0,45$ & 0,23 \\
\hline Sulfur & $\%$ & & &
\end{tabular}

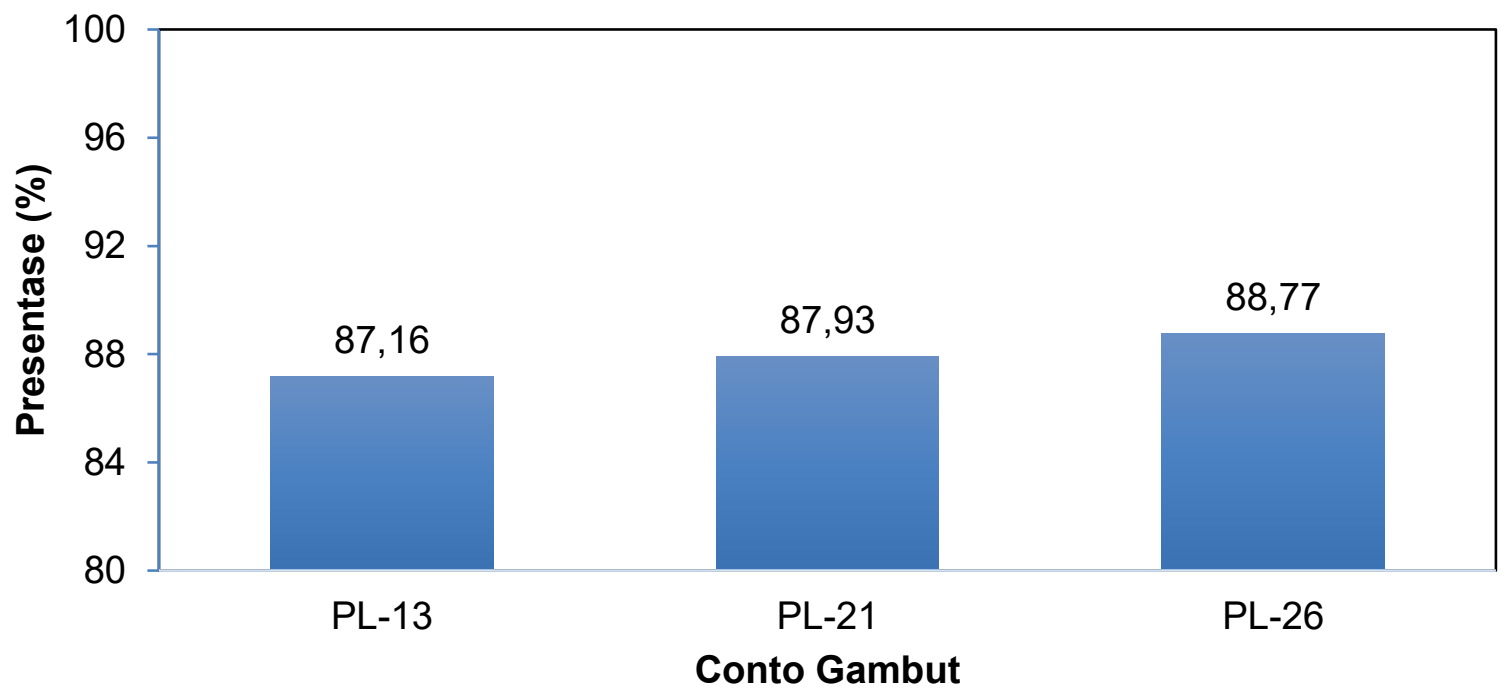

Gambar 6. Hasil uji kadar airdari tiga conto gambut Teluk Meranti

Analisis luas permukaan gambut dilakukan dengan pengujian BET (Braunanear, Emmelt dan Teller) menggunakan gas $\mathrm{CO}_{2}$. Berdasarkan hasil pengujian yang diperoleh pada Tabel 3,gambut PL-26 memiliki luas permukaan paling besar, sedangkan PL-13 dan PL-26 memiliki luas permukaan yang hampir sama.
Data hasil uji adsorpsi pada Gambar 7 menunjukkan gambut PL-13, PL-21, dan PL-26 memiliki kapasitas adsorpsi maksimum berturut-turut sebesar 15,06 ; 11,99; dan 22,93 mg/g. 
Tabel 3. Hasil pengujian luas permukaan BET menggunakan gas $\mathrm{CO}_{2}$

\begin{tabular}{cc}
\hline Conto Gambut & Luas Permukaan $\left(\mathbf{m}^{2} / \mathbf{g}\right)$ \\
\hline PL-13 & 241,73 \\
PL-21 & 241,80 \\
PL-26 & 274,29 \\
\hline
\end{tabular}

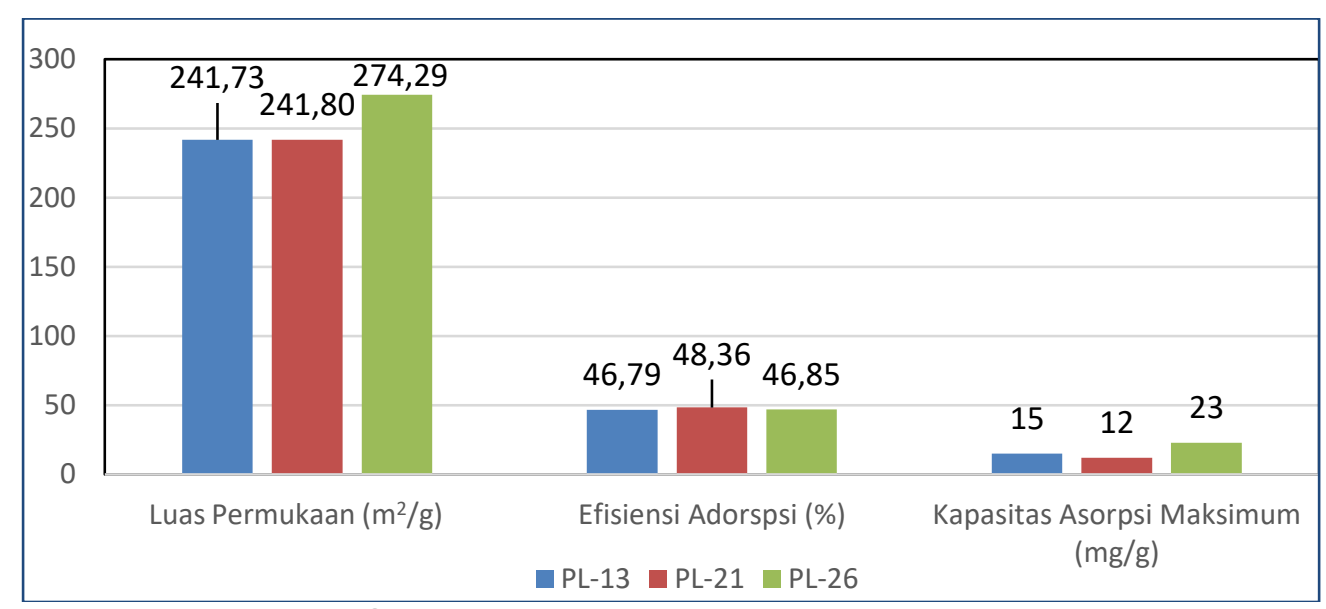

Gambar 7. Hasil uji adsorpsi gambut

\section{PEMBAHASAN}

\section{Karakterisasi Gambut Sebagai Adsorben}

Berdasarkan penelitian Oksana \& Taufiq (2017), tanah gambut mempunyai kapasitas mengikat air yang relatif sangat tinggi. Namun, sifat hidrofil ini akan berubah menjadi hidrofob (menolak air) apabila gambut terlalu kering, sehingga gambut tidak dapat digunakan sebagai adsorben. Kadar air yang diperoleh pada pengujian yang berkisar antara $87 \%$ s.d. $89 \%$ umum ditemui pada gambut yang berasal dari daerah Riau, seperti yang dilaporkan Hikmatullah \& Sukarman (2014) yang melakukan karakterisasi tanah gambut di berbagai daerah di Kalimantan dan Sumatera. Pengeringan tanah gambut sebelum pengujian adsorpsi tidak dilakukan, karena tidak seperti umumnya adsorben dari golongan karbon aktif, tanah gambut dapat mengalami penyusutan struktur (shrinkage) dan penurunan porositas yang tajam akibat pengeringan. Kajian tentang pengaruh pengeringan terhadap struktur pori dan porositas tanah gambut telah dilaporkan oleh Rezanezhad dkk., (2016). Penyusutan struktur dan penurunan porositas yang tajam sebagai akibat dari proses pengeringan yang dapat memengaruhi kemampuan adsorpsi juga dilaporkan pada batubara muda (Yuliani, 2016).

Berdasarkan hasil uji ultimat diketahui bahwa ketiga gambut PL-13, PL-21, dan PL-26 didominasi oleh unsur karbon dan oksigen secara berturut-turut sebesar $62,62 \% ; 62,05 \% ; 61,44 \%$ dan $31,84 \%$; 31,$47 ; 32.08 \%$. Kandungan unsur karbon dan oksigen yang tinggi mengindikasikan gambut berpotensi sebagai adsorben yang baik. Kandungan oksigen merupakan karakter yang penting dimiliki oleh suatu adsorben, karena oksigen yang terikat pada gugus karboksilat diyakini sebagai salah satu pusat aktif dari gambut yang dapat meningkatkan kemampuan permukaan gambut dalam mengikat ion logam. Peran gugus karboksilat sebagai sisi aktif adsorben telah dilaporkan pada literatur sebelumnya yang menggunakan batubara berperingkat rendah sebagai adsorben bagi zat warna organik (Yuliani, 2017).

Analisis luas permukaan dengan pengujian BET dilakukan untuk menentukan besarnya luas permukaan dan porositas gambut. Semakin tinggi luas permukaan dan porositas material, maka potensinya 


\section{MAKALAH ILMIAH}

sebagai adsorben semakin baik. Kapasitas adsorpsi maksimum paling besar dimiliki oleh gambut PL-26 sebesar 22,93 mg/g, hal tersebut dipengaruhi oleh luas permukaan gambut PL-26 yang tinggi dibandingkan conto yang lainnya, yakni $274,29 \mathrm{~m}^{2} / \mathrm{g}$. Efisiensi adsorpsi rata-rata ketiga gambut tidak berbeda jauh, yakni gambut PL-13 sebesar 46,79\%; gambut PL-21 sebesar 48,36\%; dan gambut PL-26 sebesar 46,85\%. Hal ini menunjukkan bahwa adsorben gambut PL-13, PL-21, dan PL-26 merupakan adsorben yang cukup baik dalam mengadsorpsi ion $\mathrm{Mn}^{2+}$.

Bila dibandingkan dengan material lain yang dimanfaatkan sebagai adsorben, gambut PL-26 termasuk adsorben yang cukup baik, karena memilki kapasitas adsorpsi maksimum yang cukup tinggi, yakni $22,93 \mathrm{mg} / \mathrm{g}$. Penelitian terdahulu melaporkan kapasitas adsorpsi sekam padi beras putih dan karbon aktif granular masing-masing sebesar 18,01 $\mathrm{mg} / \mathrm{g}$ (Tavlieva dkk., 2015) dan 7,63 mg/g (Goher, 2015). Namun, tanah liat kaolinit memiliki kapasitas adsorpsi maksimum jauh lebih tinggi dari gambut, yaitu sebesar 111,11 mg/g (Dawodu dkk., 2014).

\section{Sumber Daya Gambut Blok Teluk Meranti}

Secara administratif, Blok Teluk Meranti terletak di Kecamatan Teluk Meranti, Kabupaten Pelalawan. Sebaran gambut pada blok ini seluruhnya berada pada hutan produksi pada sistem Tata Guna Lahan Kabupaten Pelalawan dan saat ini sebagian besar lahan gambut di daerah ini telah berubah fungsi menjadi areal hutan tanam industri dari beberapa perusahaan swasta dan tidak ada permukiman masyarakat di daerah ini. Data ketebalan yang didapat dari titik pengeboran diolah menjadi isopach ketebalan endapan gambut (Gambar 8).

Gambut di daerah Teluk Meranti pada umumnya juga telah mengalami dekomposisi menengah hingga tinggi antara H5 sampai H9 (Subarnas \& Dwitama, 2019). Persyaratan lain yang cukup baik dari gambut di daerah ini sebagai bahan bakar pembangkit listrik tenaga uap adalah mempunyai nilai kalori rata-rata $5.079 \mathrm{kal} / \mathrm{gr}$ dengan kandungan abu rata-rata $0,23 \%$ serta total sulfur sangat rendah $<1 \%$, yaitu $0,20 \%$.

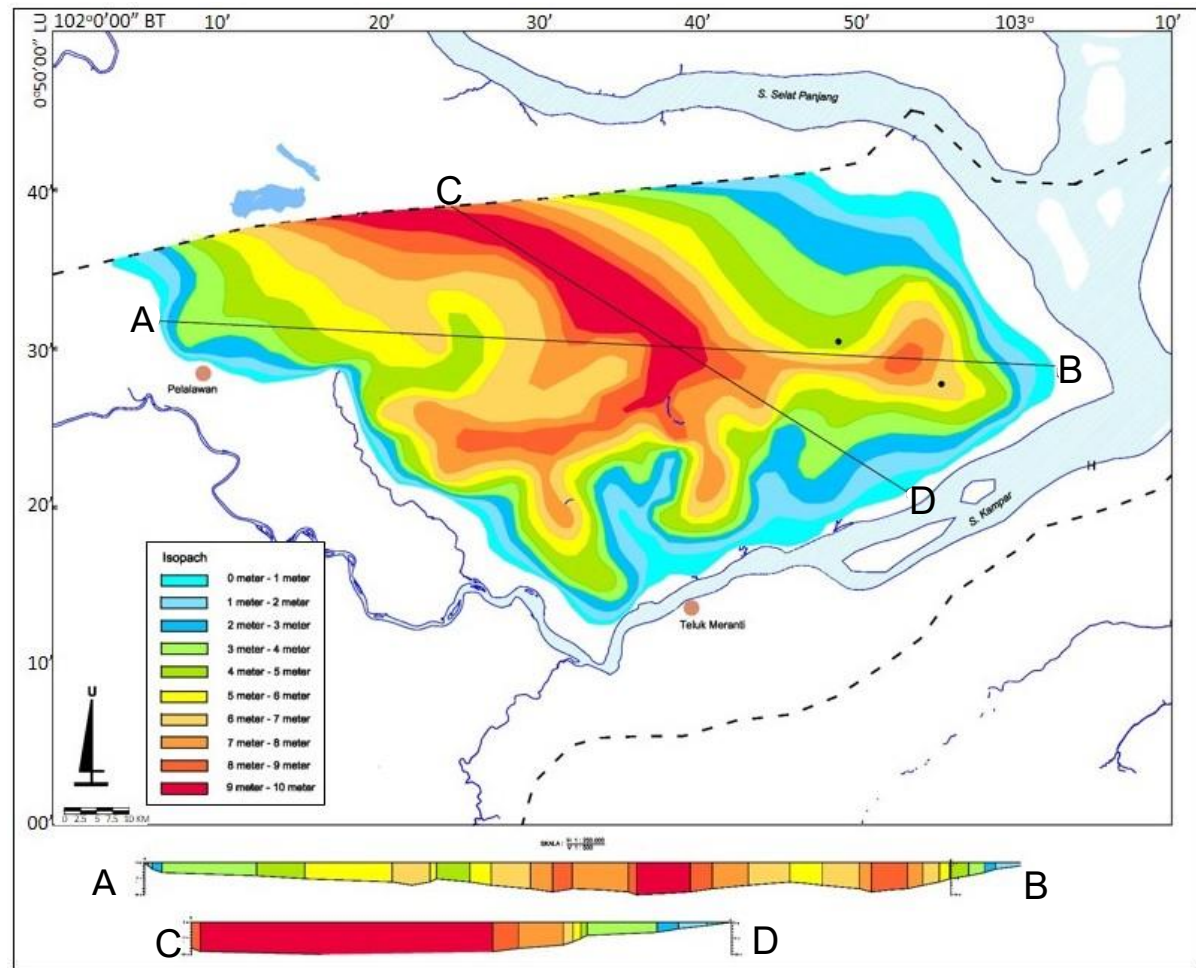

Gambar 8. Peta isopach endapan gambut BlokTeluk Meranti 
Sumber daya gambut diperoleh dari perkalian luas sebaran gambut dengan ketebalan antara dua isopah. Luas sebaran gambut dibagi menjadi sepuluh bagian menurut ketebalannya, yaitu sebaran gambut dengan ketebalan antara 0-1 $\mathrm{m}$, 1-2 m, 2-3 m, 3-4 m, 4-5 m, 5-6 m, 6-7 m, 7-8 $\mathrm{m}, 8-9 \mathrm{~m}$ dan 9-10 $\mathrm{m}$.

Berdasarkan hasil perhitungan sumber daya gambut untuk klasifikasi sumber daya tereka, maka ketebalan gambut dianggap satu meter. Dengan demikian, diperoleh besarnya sumber daya tereka sebanyak 327.619.327 ton (Tabel 4).

\section{Estimasi Sumber Daya Gambut Sebagai Bahan Adsorben Logam Berat}

Total sumber daya tereka gambut di daerah tersebut sampai dengan isopah tebal $10 \mathrm{~m}$ sebanyak 327.619 .732 ton. Peraturan Pemerintah Nomor 57 Tahun 2016 tentang Perlindungan dan Pengelolaan Ekosistem Gambut menyatakan bahwa gambut yang memiliki ketebalan lebih dari tiga meter memiliki fungsi lindung. Merujuk hal tersebut, maka gambut yang dapat dimanfaatkan untuk bahan adsorben logam berat pada blok Teluk Meranti, yaitu area Blok Teluk Meranti yang memiliki ketebalan gambut kurang dari tiga meter dengan total sumber daya tereka gambut sebanyak 90.477 .890 ton (Gambar 9).

Tabel 4. Sumber Daya Tereka Gambut Blok Teluk Meranti

\begin{tabular}{|c|c|c|c|c|}
\hline \multirow{2}{*}{$\begin{array}{c}\text { Zona } \\
\text { Ketebalan }(\mathrm{m})\end{array}$} & \multicolumn{4}{|c|}{ Blok Teluk Meranti } \\
\hline & Luas $\left(\mathrm{m}^{2}\right)$ & Tebal (m) & Bulk Density(ton $\left./ \mathrm{m}^{2}\right)$ & Sumber Daya (ton) \\
\hline $0-1$ & $228.339 .025,68$ & 1,0 & 0,10 & 22.833 .902 \\
\hline $1-2$ & $282.313 .658,51$ & 1,0 & 0,10 & 28.231 .365 \\
\hline $2-3$ & $303.174 .026,13$ & 1,0 & 0,13 & 39.412 .623 \\
\hline $3-4$ & $374.747 .840,58$ & 1,0 & 0,08 & 29.979 .827 \\
\hline $4-5$ & $431.477 .126,86$ & 1,0 & 0,10 & 43.147 .712 \\
\hline $5-6$ & $406.226 .102,99$ & 1,0 & 0,10 & 40.622 .610 \\
\hline $6-7$ & $470.572 .738,08$ & 1,0 & 0,10 & 47.057 .273 \\
\hline $7-8$ & $394.268 .453,13$ & 1,0 & 0,09 & 35.484 .160 \\
\hline $8-9$ & $212.357 .765,59$ & 1,0 & 0,09 & 19.112.198 \\
\hline $9-10$ & $217.380 .627,38$ & 1,0 & 0,10 & 21.738 .062 \\
\hline \multicolumn{4}{|c|}{ Total } & 327.619 .732 \\
\hline
\end{tabular}

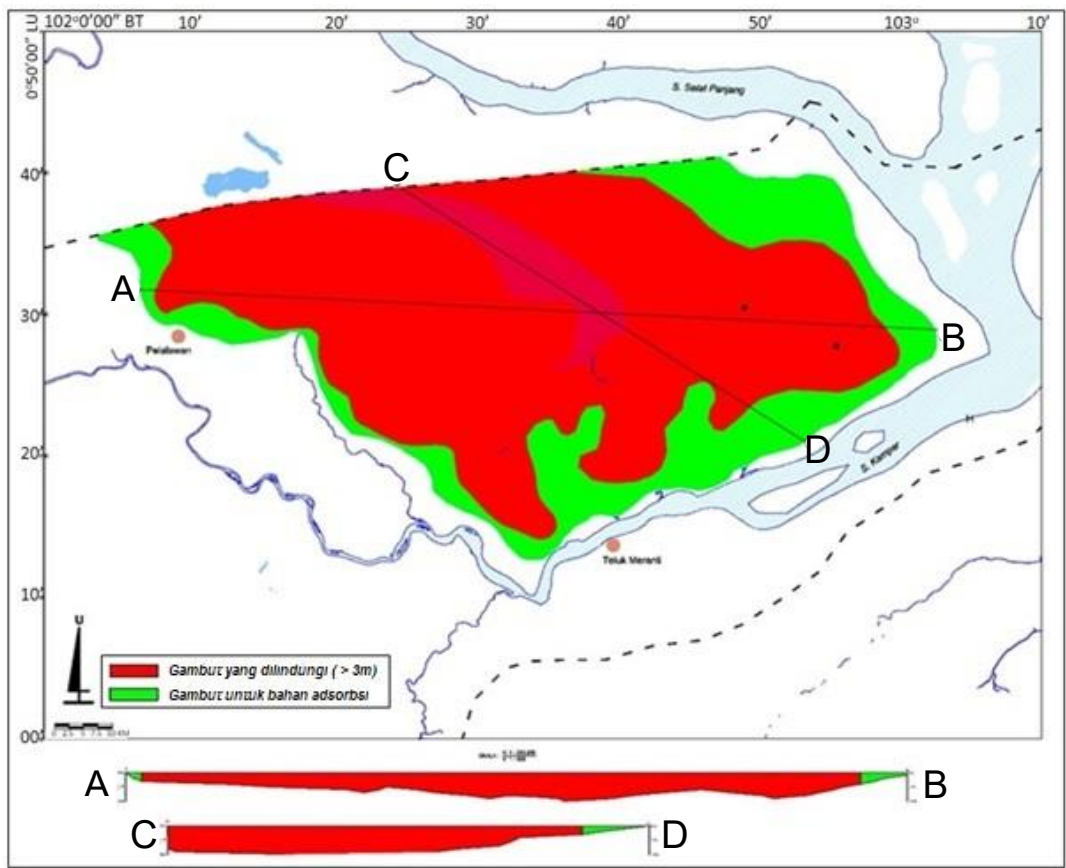

Gambar 9. Peta sebaran penggunaan lahan gambut 


\section{KESIMPULAN}

Berdasarkan karakterisasi endapan gambut pada Blok Teluk Meranti, diketahui bahwa endapan gambut pada blok tersebut memiliki potensi sebagai adsorben logam berat. Kapasitas adsorpsi maksimum paling besar dimiliki oleh conto gambut PL26 sebesar 22,93 $\mathrm{mg} / \mathrm{g}$, karena dipengaruhi oleh luas permukaan yang paling tinggi dibandingkan dengan conto lainnya, yakni sebesar 274,29 $\mathrm{m}^{2} / \mathrm{g}$. Efisiensi adsorpsi conto gambut PL-13, PL21 dan PL-26 berturut-turut sebesar $46,79 \%$; $48,36 \%$; dan $46,85 \%$. Besarnya sumber daya tereka endapan gambut pada Blok Teluk Meranti yang berpotensi untuk dimanfaatkan sebagai adsorben logam berat, yaitu sebanyak 90.477.890 ton.

\section{UCAPAN TERIMA KASIH}

Penulis mengucapkan terima kasih kepada Kepala Pusat Sumber Daya Mineral Batubara, dan Panas Bumi (PSDMBP), Badan Geologi, Kementerian Energi dan Sumber Daya Mineral, Kepala Bidang Batubara PSDMBP dan Direktorat Riset dan Pengabdian Masyarakat (DRPM) melalui skema Riset Dasar Unggulan Perguruan Tinggi yang telah mendukung penelitian ini.

\section{DAFTAR PUSTAKA}

Aditya, K., Yusnimar.,\&Zultiniar. (2016). Penentuan Model Isoterm Adsorpsi Ion $\mathrm{Cu}$ (II) Pada Karbon Aktif Tempurung Kelapa, 3(2), 1-6.

Agus, F., \& Subiksa, I. G. M. (2008). Lahan Gambut: Potensi untuk pertanian dan aspek lingkungan. Balai Penelitian tanah dan World Agroforestry Centre (ICRAFT) Bogor. Indonesia.

Bailey, S. E., Olin, T. J., Bricka, R. M., \& Adrian, D. D. (1999). A review of potentially low-cost sorbents for heavy metals. Water Research, 33(11), 2469-2479. https://doi.org/10.1016/S0043-1354 (98)00475-8
Bartczak, P., Norman, M., Klapiszewski, Ł., Karwańska, N., Kawalec, M., Baczyńska, M.,\&Jesionowski, T. (2018). Removal of nickel(II) and lead(II) ions from aqueous solution using peat as a low-cost adsorbent: A kinetic and equilibrium study. Arabian Journal of Chemistry, 11(8), 1209$1222 . \quad$ https://doi.org/10.1016/j. arabjc.2015.07.018

Boron, D. J., Evans, E. W., \& Peterson, J. M. (1987). An overview of peat research, utilization, and environmental considerations. International Journal of Coal Geology, 8(1-2), 1-31.

https://doi.org/10.1016/0166-5162 (87) $90020-6$

Clarke, M.C.G., Kartawa, W., Djunuddin, A., Suganda, E., \&Bagdja, M., 1982, Peta Geologi Lembar Pakanbaru, Sumatera. Bandung.

Dawodu, F. A.\& Akpomie, K. G. (2014). Simultaneous adsorption of $\mathrm{Ni}(\mathrm{II})$ and $\mathrm{Mn}$ (II) ions from aqueous solution unto a Nigerian kaolinite clay. Journal of Materials Research and Technology, 3(2), 129-141. https:// doi.org/10.1016/j.jmrt.2014.03.002

Dewi, P. A. I. K., Sunarya, P.,\& Sibarani, J. (2015). Adsorpsi lon Logam Pb (II) dan $\mathrm{Cu}$ (II) Oleh Bentonit Teraktivasi Basa $(\mathrm{NaOH})$. Jurnal Kimia, 9 (2), 235-242.

Goher, M. E., Hassan, A. M., AbdelMoniem, I. A., Fahmy, A. H., Abdo, M. H., \& El-sayed, S. M. (2015). Removal of aluminum, iron and manganese ions from industrial wastes using granular activated carbon and Amberlite IR-120H. Egyptian Journal of Aquatic Research, 41(2), 155-164. https://doi.org/10.1016/j.ejar.2015.04 .002

Hikmatullah\& Sukarman, (2014). Physical and Chemical PRoperties of Cultivated Peat Soils in Four TRial Sites of ICCTF in Kalimantan and Sumatra, Indonesia. Journal of Tropical Soils, 19(3), 131-141. DOI: 10.5400/jts.2014.19.3.131 
Mirwan, A., \& Wijayanti, H. (2011). Penurunan Ion Fe Dan Mn Air Tanah Kota Banjarbaru Menggunakan Tanah Lempung Gambut. Info Teknik, 12(1), 45-51.

Rezanezhad, F., Price, J. S., Quinton, W. L., Lennartz, B., Milojevic, T.,\&Cappellen, P. V., (2016). Structure of peat soils and implications for water storage, flow and solute transport: A review update for geochemists. Chemical Geology, 429,75-84.

https://doi.org/10.1016/j.chemgeo.20 16.03.010.

Skoog, D. A., Donald M, W., F, J. H., \& Stanlesy R, C. (2000). Fundamentals of Analytical Chemistry. Brooks Cole.

Stevenson. (1994). Humus Chemistry, Genesis, Composition, Reactions.

Subarnas, A \& Dwitama, E.P, 2019, Potensi Gambut Untuk Pengembangan PLTU, Di Kecamatan Teluk Meranti, Kabupaten Pelalawan, Provinsi Riau Susandi Oksana dan Ahmad Taufiq A. (2017). Analisis Sifat Fisika Tanah Gambut Pada Hutan Gambut Di Kecamatan Tambang Kabupaten Kampar Provinsi Riau. Jurnal Agroteknologi, 5 No. 2(August), 2328.

https://doi.org/10.24014/ja.v5i2.1351
Tavlieva, M. P., Genieva, S. D., Georgieva, V. G., \& Vlaev, L. T. (2015). Thermodynamics and kinetics of the removal of manganese(II) ions from aqueous solutions by white rice husk ash. Journal of Molecular Liquids, 211, 938-947.

https://doi.org/10.1016/j.molliq.2015. 08.015

Tjahjono. (2007). Kajian Potensi Endapan Gambut Indonesia Berdasarkan Aspek Lingkungan. Departemen Energi Sumber Daya Mineral (ESDM).

Wahyunto, \& Heryanto, B. (2005). Sebaran Gambut dan Status Terkini di Sumatera. In.CCFPI. Pemanfaatan Lahan Gambut Secara Bijaksana Untuk Manfaat Berkelanjutan. Wetlands International-Indonesia Program. Bogor.

Yuleli. (2009). Penggunaan Beberapa Jenis Fungi Untuk Meningkatkan Pertumbuhan Tanaman Karet (Hevea brasiliensis) di Tanah Gambut. Universitas Sumatera Utara. Medan.

Yuliani, G., Garnier, G., \&Chaffee A.L. (2017). Utilization of raw and dried Victorian brown coal in the adsorption of model dyes from solution. Journal of Water Process Engineering, 15, 43-48.

\begin{tabular}{|ll|}
\hline Diterima & $:$ 30 Juli 2020 \\
Direvisi & $: 3$ Agustus 2020 \\
Disetujui & $: 30$ Agustus 2020
\end{tabular}

